\title{
"Bedekeh"
}

\section{(Akit Tribal Ritual on Rupat Island in the Bengkalis Regency of Riau Province in the Global Era)}

\author{
Suroyo \\ Email: Roy_Pj2003@yahoo.com
}

\begin{abstract}
The Akit community have localized knowledge and accumulated wisdom that is brought to bear in addressing health problems. Bedekeh treatment is a tradition that stems from the teachings of the ancestors and it is implemented when the Akit community was in need of treatment services for diseases. This study outlines the empirical evidence concerning the problems associated with the globalization of culture. There is conflict between the values of local and global culture. The data in this study was collected through observational techniques, in-depth interviews, literature studies, and documentation. The batin and bomoh both play an integral role in the Akit tribal life cycle. The influence of globalization have influenced the use of the traditional rituals of the Akit. This has accelerated the loss of Akit oral traditions. The existence of the Akit tribal has recently been impacted by marginalization due to a number of internal and external factors. There are a number of factors affecting the growing marginalization of ritual treatment by bomoh of the Akit in tribe situated in the village of Hutan Panjang on Rupat Island. Firstly, is the effect of religious conversions by some members of the Akit. Secondly, there is the negative stigma that people from other communities associated with witchcraft. And thirdly, the development of science and technology in the treatment of health issues; including the influence of formal and informal education on Akit community and those they come in to contact with. The existence of the bedekeh ritual in the Akit is viewed essential to public service in a scientific research as a form of defence of a group of local traditions and the preservation of the culture of the nation.
\end{abstract}

Keywords: ritual, Akit, marginalization, globalization

\section{INTRODUCTION}

Bedekeh, bedikie or berdeker is one of the treatments used by the Akit tribe. Bedekeh is known as a great treatment, or ritual treatment of the sacred. There are two types of bedekeh: the ceremonial treatment (bedekekh= bedekie, beobat) and ritual sacrifice of health recovery or of prevention of illness (bedekeh bebedak). The ritual bedekeh used by then Akit tribe is estimated to have been in use in the community that inhabits the Rupat Akit territories for so many years. Bedekeh treatment is a tradition that stems from the teachings of the ancestors and it is implemented when the community was in need of treatment services.

The batin and and the bomoh both play an integral role in the Akit tribal life cycle. Both are associated with agricultural activities, with indigenous rite and rituals, and with other activities related to the customs and traditions of the tribe. This authority is vested in the village head in accordance with the laws of the villages; and as such his role is considerable because in addition to preserving the traditions and customs, he is also charged with promo thing the bedekeh ritual.
The influence of globalization and the teachings of Islam in Riau Province have influenced the use of the traditional rituals of the Akit. The entry of Islamic groups into the region resulted in The religious teachings that were contrary to the ritual traditions, and one of the effects of those teaching was the emergence of individuals and groups that opposed the traditional of local communities - rituals that these individuals and groups claimed were mystical and shirk (the jin, in Islam, of practicing idolatry or polytheism). This has accelerated the loss of Akit oral traditions. More recently, newer generations have been affected by modern education, and this also has had a negative impact on the implementation of the bedekeh ritual.

Modern medicine with modern (Western) epistemology equates treatment via the health service program of the Department of Health as equitable development. This then implicates and ultimately affects traditional community life and traditional community values. 


\section{RESEARCH METHODS}

This research is qualitative research using participation, observation and in-depth interview. Next, snowballing technique discovered and applied by Spradley (1997:61) and Benard (1994:61) is applied. In this technique research can be terminated if the data has been repeated and the data is sufficient or if perceived saturation values have been reached (where there is no new information available). Data sources consists of primary and secondary data. The primary data source is the Batin and the shaman, as key informants. Primary data was also obtained from informants and observations about the bedekeh ritual. Secondary data comes from archives, customs documents, and a monograph of the village. The research on Akit bedekeh tribal rituals is a qualitative study was designed in accordance with the scientific paradigm of cultural studies. This research was conducted in the village of Forest Long, District Rupat in the Bengkalis District of Riau Province. The Akit tribe was selected as the study site, on the basis that (1) empirically the bedekeh ritual is occurring there, (2) the bedekeh ritual has an important role for Akit tribal, (3) (3) the implications of the marginalization of bedekeh ritual in the global era are apparent in this site, and (4) the result of attempts at preservation of the bedekeh ritual in the global era is in evidence.

\section{RESULTS AND DISCUSSION}

The bedekeh ritual of the Akit tribe has four important components:(1) merancang is the design of the ritual, the key element of which is the determination of a suitable place in which to hold the ritual; (2) ensuring that the confidence of spirits and of the ancestors is gained with the assistance of drugs; (3) selection of the bomoh as master of ceremonies and rituals; and (4) the ceremony of bedekeh by the bomoh in the treatment of patients.

The bedekeh ritual is an activity that is full of meaning, has a certain power, involves religion, and reflects the identity of the Akit tribe. It is in every sense, a very complex ritual. Hamidy (2009:21-22) says that in every tradition rites and other rituals are often encountered develop area. Each ceremony will include space, time, and place of execution, texts (messages of the ceremony), and participants of the ceremony.

The ritual bedekeh used by then Akit tribe is estimated to have been in use in the community that inhabits the Rupat Akit territories. Bedekeh means remembrance and thought, how thought over how the treatment of existing disease on Akit society to repel evil spirits cause illness in Akit people's lives. All diseases according to the Akit are believed to be caused by the interference of supernatural spirits or antu (ghost), a disorder of the ancestral Akit and treatment of others, and a curse. Foster and Anderson (1986:63) have also undertaken earlier research on the place of the other states of suffering: pain caused by the presence of agents (middlemen), both in the form of supernatural creatures (supernatural beings or gods), non-human beings (ghosts, ancestral spirits or demons), as well as humans (witches or sorcery).

The ritual of bedekeh contains ideology which became the central to the cultural values of the Akit tribe. The ideology is divided into two parts: the ideology of religion and of cosmology. The ideology of the cosmology of the bedekeh ritual is associated with the Akit's belief about the process of creating the macrocosm (the universe) and microcosm (humans), whereas religious ideology is associated with ethnic conceptions about the relationship of humans with Akit ancestors and with God. The bedekeh ritual is not merely an emotional reaction to the illness it is treating, but rather it is designed to keep the harmony of humans with the cosmos. In maintaining the harmony of human nature, its adherents will be reminded that there are other forces beyond the range of the human mind.

Traditional treatment through the bedekeh ritual still survives and is practiced in public life despite the Akit knowing about the positive effects of modern medicine. For researchers, the bedekeh ritual is considered important as it uncovers a variety of magical values contained in these rituals, and this research is seen as useful for people who require alternative healing. In addition, it is also beneficial to the development of culture. According to Giddens (2003:67), globalization brings the principles of cultural modernity that give rise to various social problems in human civilization. This threatens the existence of local culture, and in the worse instances leads to the extinction of local culture.

Bedekeh ritual is important for researchers seeking to uncover the basis of the magic contained in these rituals and in understanding why it is useful or important to people who seek alternative treatments. In addition, it is beneficial to the understanding of the development of culture. Giddens (2003:48-50) states that as a custom or tradition, it suggests a habit, which is a marker of identity both personal as well as collectively (that is, as a community). Constancy is the creation of identity in the course of time, connecting the past with the future owners of the community with the reality of broader social identity.

The phenomena presented above would threaten the existence of local culture, even driving it to extinction. Globalization is by virtue of the economic forces that drive it, and the power of the dominant country or countries leads to the ideology associated with the dominant country or countries being disseminated either through the media and information technology and through education. To be able to survive in this era of globalization, any given individual, group, or nation needs to have its own identity (Tilaar, 2007:1-2). The process of globalization is, in fact, the globalization of the economy and refers to a set of economic activities as the practices of capitalism. However, it impacts cultural significance by the virtue of the existence of global cultural processes (Barker, 2006:150151).

Marginalization the Bedekeh Ritual

1. The Power Relations in Religious Conversion by the Government 
By reason of majority hegemony, the Akit tribe do not have a guarantee of religious freedom because it doesn't follow one of the "officiall religions. Regulations issued by the Government bring a complicated impact to the survival of the Akit tribe on Rupat Island in the Bengkalis Regency of Riau Province. Various religious figures officially recognized by the Government are attempting to target to the Akit through missionary activity or preaching. When a citizen applies for a compulsory identity card, he or she must specify one of the six religions permitted by the Government. The Akit cannot determine his or her religious identity, one that is of the region from where he or she originates. This show that the country is still treating them as second class citizens.

Government sanctioned discrimination, stems from the enacting of law No.1/PNPS that says that the religions recognized by the State are Islamic, Christian, Catholic, Hindu, Buddhism, and Confucianism. The impact is that none of the laws that provide back-up for local tribal religions such as Akit are recognized in Indonesia. In order for the tribe's survival in the country and to be recognized as part of Indonesia, the Akit are forced to join (whether through conversion or just in name) one of the religions that have been recognized in the country.

\section{Akit Stereotypes in the Perceptions of Malays}

The stereotyping of the Akit tribe means that they are often positioned as on the periphery and put in a low position in the social hierarchy of the lowest 'Malay' world. They are not part of what is called by the Malay hierarchy as 'the people' (nation of Islam), a term that is used to refer to the Malay people who are 'homogeneous'. They are not the people charged with protecting the Malay customs, not Islam, not even speaking in Malay dialect, even though they look like the Malay people. The construction of the social structures that still affect the Malay people until now will damage the important symbols in the image of the life of the Malays. Practical manifestations of those things, for example, include religious rituals, the procedures for marriage, naming, food preferences, funeral rites, etc.

\section{The entry of Modern Medical System}

The influx of modern medicine to Indonesia along with the expansion of the West to the East, has impacted countries including Indonesia in general and the Akit in particular. The world of modern medicine rationally reduces the need for and the presence of the non-rational shaman or bomoh. Modern health institutions and treatments such as doctors, hospitals, health centers, clinics, modern medicine and others slowly diminish the impact of traditional medicine. Modern education also teaches that modern medicine is best. Rules and policies of the government legitimize modern medicine as a recognized treatment method. As a result, the existence of the bomoh/shaman and traditional healing practices will be increasingly marginalized.

\section{Education and Technology Progress}

Education and knowledge, information technology and modernity that have impacted the ethnic Akit also are the cause of the marginalization of the bedekeh ritual. Formal education can transform habits and behavior, in particular the community customs of the Akit in treating mythical things or the supernatural. The development of modern science and technology that puts economic value in rational logic tends to shift the existence of tradition in the community.

\section{Shifting Positions Bomoh / Inner for Rural Law}

Control of these socio-cultural system, institution, habits, and customary law is taken over by the batin of the village with all his officer at Desa Hutan Panjang District Rupat, Bengkalis District, Riau Province. The Batin is the center of power and authority in the local rankings because he has various skills that are seen as desirable. This is very different to the village head. He may not necessarily be the center of power and does not have the authority. Structural changes in the tribe may occur due to various factors, among which are changes in government policy, education, the environment and changing interests. In some cases national government policy has brought changes to the Batin's relationship with the tribe, and the overlaying of national law on village administration has led clashes between traditional norms and national norms. Thus the elimination of customary norms, rituals treatment means that the batin loses his legitimacy to lead society.

\section{The Bomoh Minimal Income}

Akit bomoh devote their lives to the life of the tribe trying to avoid interruption, disorder, disease or disaster that would otherwise disrupt people's lives. The job as a bomoh is to solely devote oneself to the village. For the younger generation now, however, success is measured by money so the profession of bomoh has precisely no interest to them. The profession of bomoh has no clear wage standards, and indeed is not related to money, but rather is related to the statisfaction on the individual.

\section{IV.CONCLUSION}

The implementation of bedekeh rituals contain an enormous amount of local wisdom, symbols and values and all this impacts the public life of the bomoh and his supporters. Tribal life practices of the Akit that blend the customs and culture provide the belief systems that are inherited for safekeeping for future generations. The ritual bedekeh of the Akit tribe, besides being a treatment for medical issues, is an integral part of the social structure of the culture of Akit ethnic communities and it should be recognized that these contain religious values.

Local culture must be maintained as part of cosmology, a system of rituals, and magical beliefs. The existence of the bedekeh ritual by bomoh has become increasingly marginalized by modernization. In the life of ethnic communities in the villages of the Hutan Panjang district 
Akit, Bengkalis Regency, each phase of the life cycle of their community is influenced by a bomoh. In practice, the bomoh is dominant in all aspects of their lives. Globalization and Government policies have resulted in the marginalization of the bedekeh ritual by Akit bomoh. Therefore, there is a need to protect and preserve community cultural rituals such as bedekeh by the Akit bomoh for the sake of continuity.

\section{REFERENCE}

Barker, Chris. 2006. Cultural Studies: Teori dan Praktik. (Tim KUNCI Cultural Studies Centre, Pentj). Yogyakarta: Bentang Budaya.

Benard, R, H. 1994. Methods in Anthropology. LondonNew Delhi: SAGE Publications.

Foucault. 2002. Power/Knowledge Wacana Kuasa/Pengetahuan (Penerjemah Yudi Santosa). Yogyakarta: Benteng Budaya.

Foster,G.M. \& Anderson. 1986. Antropologi Kesehatan. Jakarta :UI Press.

Giddens, Anthony. 2002. Tradition dalam Runaway World: How Globslization is Reshaping Our Lives, London: Profile Books.

Hamidy, U.U. 2009. Kebudayaan sebagai Amanah Tuhan, Pekan Baru: UIR Press.

Hamelink.Cess J. 1983. Cultural Autonomy in Global Communications: Planning National Information Policy, London: Longman.

Kleiden, Paul Budi. 2015. "Ambivalensi para Leluhur: Menafsir Ritus Tu Dhe'U di Palu'é Berdasarkan Teori Kambing Hitam René Girard”. Dalam: Julian C.H. Lea \& John M. Prior., (ed). Pemburu yang Cekatan: Anjangsana Bersama Karya-Karya E. Douglas Lewis. (Yosef Maria Florisan, Pentj). Yogyakarta: Ledalero.

Osawa, Takamasa. 2009. Shamanistic Practices Among The Akit of Eastern Sumatera. Tesis Tokio University.

Pudentia, MPSS. 2008. Metodologi Kajian Tradisi Lisan. Jakarta: ATL.

Suroyo.2017. "Ritual Bedekeh Suku Akit di Pulau Rupat Kabupaten Bengkalis Provinsi Riau Pada Era Global.” (Disertasi). Denpasar: FIB Universitas Udayana Denpasar.

Spradley, J. P. 1997. Metode Etnografi. Yogyakarta: PT Tiara Wacana.
UNESCO. 2009. Berinvestasi dalam Keanekaragaman Budaza dan Dialog Antarbudaya. Laboran Dunia UNECO, no 2 United Nations Educational, Scientific and Cultural Organizations.

UU RI No 36 Tahun 2009 Tentang Kesehatan

Tilaar, H.A.R. 2007. Mengindonesiakan Etnisitas dan Identitas Bangsa Indonesia. Jakarta: Rineka Cipta 